\title{
White-Collar Activism in the Digital Age: The Case of "Plaza Action Platform" on Twitter
}

\author{
Ayşe Fulya Şen \\ Department of Journalism, Firat University, Elazig, 23119, Turkey \\ Email: fulyasen@firat.edu.tr
}

How to cite this paper: Şen, A. F. (2018) White-Collar Activism in the Digital Age: The Case of "Plaza Action Platform" on Twitter. The Educational Review, USA, 2(10), 499-504.

http://dx.doi.org/10.26855/er.2018.10.001

Corresponding author: Ayşe Fulya Şen, Assoc. Prof. Dr., Department of Journalism, Firat University, Elazig, 23119, Turkey.

\begin{abstract}
"Plaza Action Platform" is a solidarity network providing content related to business law, sharing experience, and work-based issues. In this study, I will discuss the role of digital media practices within the labour movements and analyse the potential of the website of "Plaza Action Platform (PEP)" in creating a democratic platform for class-based issues. I will also investigate how the "Plaza Action Platform" aiming at being the voice of white-collar employees and unemployed mobilises the followers and activists to participate in online and offline activism. Also, I will assess the activism performance of PEP by content analysis over the categories such as creating a counter-public sphere and activist resistance. Thus, I will investigate the mobilisation capacity of PEP and analyse how it utilise the Twitter to organise actions, share information, and coordinate at a distance. Finally, I will also discuss to what extent the activists and the relevant public use social media platforms as means for mobilisation and how this kind of solidarity platform creates an alternative public sphere among the online audience, and how it encourages activists to participate offline.
\end{abstract}

\section{Keywords}

Digital Activism, Social Media, Labour Rights, Resistance, The Plaza Action Platform

\section{Introduction}

For several decades, the distinction between 'white-collar' and 'blue-collar' work occupied a central place in the analysis of working-class consciousness. According to many scholars, the expansion of non-manual employment was key to dismantling traditional working-class identities (Pérez-Ahumada, 2015). It is argued that in the face of the escalating automation of the workplace, fierce labour rivalry at both national and international levels and the decline in the current labour organisations projections, anti-establishment labour movement sounds have increased. The concentration of a vast number of workers in telecommunications, transport, banks, hospitals, energy sector, and the like can today paralyse the capitalist economy as efficiently as their "blue-collar" counterparts in the manufacturing industry. Furthermore, "professionals" and salaried employees such as teachers, engineers, physicians, and even middle and lower level managers are increasingly becoming wage workers and are thus ruled by the supply and demand forces of the labour market (Zadeh, 2016).

Privatisation has a fragmented collective organisation in the public sector reinforcing a more general decline in collective bargaining. In global capitalism period, it is seen the collapse of collective bargaining in the private sector and its attenuation in the public sector through privatisation.The privatisation of services, often based upon an ethnic division of labour underpinned by state immigration policies, limits the development of structures of engagement for migrant workers. Materially, the rela- 
tionships between work and class, race, gender and ethnicity are explicit and defined by the wider relations of a capitalist system. The articulation of these material relationships is dependent upon political organisation and language, which may crystallise or privilege one particular identity at the expense of others. In the 1980s it was commonly argued that shifts in values and lifestyles supposedly encourage individualism and privatism leading to a decline in class-based politics. The class-consciousness and class awareness no longer exist (Moore, 2011).

The economic system of Turkey was based on a planned development model and the import-substitution industrialization of the pre-1970 era. However, in line with the neo-liberalization efforts in many other countries in the late 1970s, Turkey liberalized the market mechanism to converge the national economy with global capitalism. This structural change came with the January 24, 1980 measures, which were reinforced by the September 12, 1980 military coup. In 1983 the liberal Özal government came to power and obtained the support of the International Monetary Fund (IMF) and the United States (Inal and Akkaymak, 2012). In Turkey, the inclusionary developmental state of the 1960s-70s transformed into the institutionalised of a new form of state called "the neoliberal exclusionary state" in the 1980s. The pivotal aspect of the neoliberal exclusionary state was the exclusion of organized labour from the political process and its disciplining in the economic sphere. The balance of power was shifted in favour of capital and Turkish economy was reconstructed towards an open market and export-oriented model. In the 1980s, centrally organised interventionism was applied against organised labour to discipline and weaken it. Also, the state actively intervened in labour-capital relations to control, weaken, or dismantle institutions, specifically labour unions, strike activity, and collective bargaining (Önder, 2016).

The media have echoed management's claims in place of workers' in the strikes and the violations of the right. The workers have lost bargaining power in the face of the decline of the workforce due to the robotization in the industry and the decreasing proportion of union members in total employment. The new system called "disorganized capitalism" means that the integration of capital and labor with the state is considerably loosened. While nowadays workers are increasingly invisible in public representations, other subject-positions such as gender, ethnicity, religion much more are emphasized. Cultural identities have displaced the class in the global capitalism period (Aronowitz, 1992). The history of the labour movement and its relation to the mainstream media has long been viewed as one of antagonism and misrepresentation. Given the oppositional role of capital and the state, the labour movement has often played to disseminate socialist-inspired ideas about a society built on principles of mutual aid, cooperation, self-help and direct action. Thus, it is exposed to be either destroyed, curbed or co-opted by the main political and economic institutions. The control of language and the representations of events through media is also an attempt to control the way in which people thought about the social world. With the emergence of elite-led neoliberal political and economic movements in the 1970s, the US model of commercial profit-seeking media has now become the global norm displacing public service models (Dencik and Wilkin, 2015).

The labour movement is benefited from advantages of new media and uses new Internet-based platforms to promote and organise their activities, so a counter- media is crucial for the labour movement. The potential of Internet for activism has been discussed in media studies. Many researchers have focused on democratic aspects of the Internet as a public sphere providing a democratic platform for citizens. This feature can be used to mobilise people or to deliver data on a mass scale. Thus, the networks have been able to internationalise easily, and experimentation has flourished due to the lack of centralised control (see in Tatarchevskiy, 2011; Feenberg, 2014). The social movements, civil society organisations, and the acts of public oppositions have used the Internet to post information and videos, promote their causes, and solicit new members (Croteau and Hoynes, 2014).

The Internet has drastically altered the cost structure of participation, and has also increased the spectrum of possible political activities. Via the Internet, a citizen can forward e-mails with political content and try to influence government decisions through comments posted on websites. The existence of new types of action can only serve to increase the total level of politi- 
cal participation. Impacts on levels of participation depend on the extent to which the new channels are used (Anduiza et al., 2009). The nature of digital activism, the relationship between online and offline mobilisation and organisation, the use of social media platforms for resisting and challenging forms of domination and institutions of power compose some key points of activism process. Digital and social media create the platforms to share information and news about workers' struggles and union campaigns that are neglected in traditional mainstream media and puts pressure on corporations and political elites. Digital activism is the form of activism that uses the Internet and digital media as key platforms for mass mobilization and political action. Digital activism has proved to be a powerful means of grassroots political mobilization and provides new ways to engage protesters (Fuentes, 2014; Dencik and Wilkin, 2015).

"Plaza Action Platform" is a solidarity network providing content related to business law, sharing experience, and work-based issues. In this study, I will discuss the role of digital media practices within the labour movements and analyse the potential of the website of "Plaza Action Platform (PEP)" in creating a democratic platform for class-based issues. I will also investigate how the "Plaza Action Platform" aiming at being the voice of white-collar employees and unemployed mobilises the followers and activists to participate in online and offline activism. Also, I will assess the activism performance of PEP by content analysis over the categories such as creating a counter-public sphere and activist resistance. Thus, I will investigate the mobilisation capacity of PEP and analyse how it utilise the Twitter to organise actions, share information, and coordinate at a distance. Finally, I will also discuss to what extent the activists and the relevant public use social media platforms as means for mobilisation and how this kind of solidarity platform creates an alternative public sphere among the online audience, and how it encourages activists to participate offline.

\section{Theoretical Framework}

The network formation of the Internet encourages people for communication. Also, new media represent a dynamic form of participation in social and political issues. The alternative and critical public spheres created by new media provide a forum for individuals and groups on the debates. Thus, new media has become a platform for open discussions and public activism. As Bennett (2003) indicates, activist networks use new digital media to coordinate activities, plan protests, and publicise high-quality information about their causes. When it is considered that the press and officials criminalise many activists, the activist networks reach to the public via alternative media and social media platforms. Bennett (2003) draws attention to news coverage of demonstrations is often filled with images of violence and hooliganism. Norris (2007) emphasises that in today's world, alternative channels of political engagement, mobilisation, and expression rapidly emerge in modern societies, including the general rise of demonstrations and protest politics. Social movements, online political communities, and transnational policy networks constitute new patterns of political activism.

Social media today is largely a visual experience. Besides to texts, images and videos are also key to today's digital society. Visuality and visibility have a function to provide social expression and connection. In a digital society, the interaction and communication between people through the use of images on social media platforms like Instagram and Snapchat and through videos on sites such as YouTube are prime examples of the cultural tendency towards a prominence of imagery. It is acknowledged that the forms of bottom-up digital activism - in the form of uprisings, revolutions, and protests- can be used successfully to challenge, provoke, and overthrow the prevailing power structures. Despite the trial of strength between cyber-optimism and cyber-pessimism, digital activism studies claim that the internet and social media can create networks of resistance. Hence, digital media have contributed to the alignment of diverse social movements, and to challenge traditional forms of political representations (Lindgren, 2017).

The literature on the role of the Internet and social media regarding democratisation and digital activism has centered on a dichotomy between optimists and sceptics. Whereas the optimist view argues that the Internet and other forms of electronic 
communication might contribute to a new kind of public sphere and potentially a new kind of democracy (Bohman, 2010) and assumes that the Internet might also promote social movements (McCaughey and Ayers, 2003), the sceptic view indicates some limitations of Internet-based activities. Accordingly, the Internet is unable to create the necessary trust and strong ties that are required to build a sustainable network of activists. These restrictions make clear that even an extensive digital action repertoire will not, and probably never will, be able to replace traditional forms of activism and face-to-face communication (Van Laer and Van Aelst, 2010). Also, Lynch (2011) for example, argues that while social media "offer powerful tools to protest organisers, reducing transaction costs for the organisation and presenting rapid and powerful channels, "they do not necessarily translate into enduring movements or robust political parties” (Lynch, 2011). Social media offer new challenges and new possibilities, and create new requirements for the study of multicultural discourses. Social media now provide a site of fundamental shifts in communicative practices. Social media are described as the main force behind the popular movement against authoritarian regimes in the Middle East and North African region. Twitter, in particular, has been pinpointed as the fastest and most critical campaign tool for reaching and mobilising people (Bouvier, 2015).

There is a widespread perception that the Internet is an inherently democratic technology. Accordingly, the Internet is a vehicle for extending democracy in social and cultural life. The Internet enables new forms of political activism and enhances democracy by engaging with previously marginalized communities. The ecology and peace movements make extensive use of the Internet as a vehicle both for disseminating information and organizing activists. The other contention is that the Internet will transform and enlarge the notion of democracy. In this view, the public sphere is expanded and takes on multiple forms that open up new places from which to speak. The public sphere is a space for the democratic exchange of ideas (Barker, 2012).

Kavada (2005) points out the Internet, hailed as the medium to breathe new life into civil society and the public sphere, and its political potential. Optimists hope that the Internet will increase the pluralism of voices within the public sphere by providing a space for non-mainstream and fringe organizations to publish their opinions. Its networking capabilities can also be used to strengthen the bonds between different organizations, fostering solidarity and a sense of mutual support. Furthermore, by encouraging participation and online deliberation, the Internet can deepen the involvement of the public with civil society organizations. The optimism around the Internet and its political potential are linked to a belief in its publication and networking capabilities. As a publication medium, the Internet provides a space for political organizations to publish their opinions and gain a foothold in the public sphere. Dahlgren (2014) argues that social medias do not automatically result in politics, protest and political participation, but have the potential to foster political struggles and engagement. Being in a political discussion online is an important step but would not automatically constitute political participation.

New media is characterised by digitisation, convergence, interactivity and the rise of networks. While social networking sites connect people with each other, they also produce an active public sphere. New media has the potential to undermine established practice and open up the possibility of a more pluralistic public sphere through their interactive capacities. Furthermore, the development of new media extends individual activity into the realm of negotiating interactive communication such as user-generated content and variety of alternative sociopolitical and cultural activity (Wessels, 2014). Protest actors also circulate imagery on the Internet. Protest images are spreading in a globalised media sphere. On the one hand, social movements attract public attention for their aims and actions by providing the media with attractive image events. On the other hand, the news value of contentious pictures is increasing, both in terms of attention value and in terms of the global dissemination of images. While for a long time, access to the mass media restricted the efficiency of public protests to local events; the Internet is offering new possibilities for attracting public attention and mobilising supporters on a global scale (Ludes et al., 2014).

\section{Literature Review}

Political activities on the Internet have become more impressive recently. Since the Zapatista movement in Mexico in the early 
1990s and continuing with the protests against the WTO and IMF, the worldwide demonstrations against the War in Iraq and the Occupy movement. The recent Arab revolts are also proof of the political potential of the Internet. These examples indicate that the Internet is the main tool of different communities and it enlarges the public sphere. The most innovative aspect of the Internet is its capacity to support such a collective reflection on participant interests in all domains of life (Feenberg, 2014). Vegh (2003) defines online activism as a politically motivated movement relying on the Internet. Activists take advantage of the technologies and techniques offered by the Internet to achieve their goals and divides online activism into three main categories: Awareness/advocacy, organisation/mobilisation, and action/reaction. Firstly, public awareness is achieved by accessing information. The Internet serves alternative news and the news focusing on issues not reported or misreported in the mainstream media are provided by independent organisations. The forms of obtaining information include visiting relevant websites or participating in different types of email distribution lists. The second step of online activism is the organization or mobilisation. The Internet can be used to call for offline action or an online action. The most efficient way is to set up a Website providing information. The third step also contains the proactive and aggressive usage of the Internet. The first well-known example is the pro-Zapatista movement in support of the struggle of the indigenous people of Chiapas against the oppression of the Mexican government, and the Internet has provided an advanced communication space. A group of activists and artists engaged in practising what they call "electronic civil disobedience." Similarly, the global resistance took place against the World Trade Organization. The Internet was used to launch an online attack against the website of WTO. The Internet became the battlefield upon which to resist globalism and cultural hegemony.

Jeffrey (2008) has examined emerging norms, forms, and technologies within anti-corporate globalisation movements based in Barcelona. Accordingly, anti-corporate globalisation movements organising protests against multilateral institutions in cities such as Prague, Barcelona, Genoa, Quito, and Cancún involve an increasing confluence of network technologies, organisational forms, and political norms, mediated by actual networking practices and micropolitical struggles. He also points out the digital technologies to communicate with activists in other countries and how computer- supported networks, including activist media projects, Listservs, and websites have mobilised hundreds of thousands of protesters, constituting "transnational counter-publics."

The Zapatista uprising, which started in 1994, and the 'Battle of Seattle' in 1999 is used two iconic examples to illustrate how the Internet shapes social movements and the tactics they use to pursue their claims. Moreover, Barack Obama's campaign in 2008 built upon this basic strategy, incorporating social networking, voter outreach, volunteer opportunities, and video clips on its website. By inspiring from this model, Internet-based politics has encouraged the online political activist organisation. The Occupy Movement, the Arab Spring, and the Gezi protests in Turkey are amongst the best known examples. The iconic examples illustrate how the Internet shapes social movements:

- $\quad$ The Zapatista uprising in 1994

- $\quad$ The 'Battle of Seattle' in 1999

- $\quad$ The Arab uprisings in 2011

- $\quad$ The Occupy Movement in 2011

- $\quad$ The Gezi protests in 2013

During the Gezi Park protests of summer 2013, social media use in Turkey increased sharply, and the Internet created a platform for horizontal communication, activist organisation and political participation. Yesil (n.d.) argues that Turkey's thriving Internet culture is related to the widespread government propaganda and the absence of a critical journalistic perspective towards the government. As Yesil (n.d.) notes, the Gezi protests were either ignored by mainstream media or characterised by negative representations. Therefore, in response, protesters used social media, especially Twitter, to fill the information void left by mass media, to counter government propaganda and to show the police violence and thus Twitter became the most prominent tool for 
protesters and information-seekers alike. Güner (2016) draws attention to the possible effects of social media on politics and analyses the protests and demonstrations organised through social media in Turkey starting from May $2013 . \quad$ She argues that while these new media have shaped the structure of politics through promoting "contentious collective action", social media have not produced radical outcomes such as a government change. Güner (2016) also indicates that although there is strong evidence that social media was influential in Gezi protests both as an organisational tool and as an alternative press, "the aftermath of Gezi Protests, in fact, shows that Revolution is not just one tweet away, nor it will be tweeted".

\section{Research Design}

The Plaza Action Platform defining itself as a solidarity network of the white collars employees is a civic formation aiming at protecting the labour rights. The Plaza Action Platform is an independent formation created by white-collar workers to develop solidarity among them, to gain skills in organization, rights production, and defense, and to be a part of the labor front. In particular, it aims to create awareness through experience sharing workshops, declaration manifestos against employers, and solidarity awareness through psychosocial solidarity activities (Plaza Eylem Platformu, 2018). In this study, I have carried out a content analysis over the tweets of the Plaza Action Platform, investigated the tweets containing certain keywords related to activism, offline street movements, and labour rights, thus attempted to show the mobilisation capacity of PEP via Twitter. I have also conducted a descriptive analysis through the frequency distribution. I have included all tweets shared up to August 10,2018 , in the research and examined total 6386 tweets.

\section{Findings and Analysis}

Firstly, I have indicated the main characteristics of the Twitter account of the Plaza Action Platform. The number of follower and following are the indicators of vividity of the account and the wide of the audience reached (Table 1). The secondly, I have displayed the digital activism potential of PEP through the certain keywords (Table 2).

Table 1. Twitter account attributes of @plazaeylem (10 $0^{\text {th }}$ August 2018).

\begin{tabular}{lc} 
The number of followers & 4847 \\
\hline The number of following & 1594 \\
Photos and videos & 330 \\
Total number of tweets & 6386 \\
\hline
\end{tabular}

Table 2. Mobilization capacity of the Twitter account of PEP (by $10^{\text {th }}$ August 2018).

\begin{tabular}{lll}
\hline Keyword & Number of tweets containing the keywords & $\begin{array}{l}\text { Total number of tweets } \\
(\mathbf{1 0} \text { August 2018) } \\
(\mathbf{n = 6 3 8 6})\end{array}$ \\
\hline Resistance & 29 & 6386 \\
Struggle & 18 & 6386 \\
Class-struggle & 0 & 6386 \\
Protest demonstration & 27 & 6386 \\
Strike & 40 & 6386 \\
Unemployment & 20 & 6386 \\
Labour rights & 2 & 6386 \\
Capitalism & 5 & 6386 \\
Employment security & 4 & 6386 \\
Trade Union & 27 & 6386 \\
Total & $\mathbf{1 7 2 ( \% 3 7 . 1 2 7 )}$ & $\mathbf{6 3 8 6}$ \\
\hline
\end{tabular}


The number of the followers and sharings points out the boundaries of a counter-public sphere consisting of different labour groups, and its interactivity capacity. It is possible to say that this space seems very narrow when considered around Turkey scale. Although the website of PEP is more active than Twitter and has a content related to the labour issues, Twitter page attractiveness seems low level and is not looked like a dynamic activist platform. Although it struggles against class-based inequalities and the labour issues, hardly can these kinds of organisations transform established mainstream political thought.

Firstly, In order to gain an insight into the activism capacity of PEP through the particular keywords related to the activism and resistance such as struggle, resistance, and strike etc., I have counted the tweets containing these words. As can also be seen from the Table 2, the emphasis on the "strike" is higher than the other concepts. Subsequently, the resistance, trade union, protests demonstration, unemployment, and struggle concepts have been ranked. Although all of them refer to the call for activism for the labour rights, this is low level comparing to the total of the tweets. It only represents $37 \%$ of the tweets. Furthermore, These concepts such as "capitalism", "class-struggle", "employment security", and "labour rights" have less the tweet coverage. Hence, PEP carries out a struggle and looks for a solution within capitalism, instead of being against capitalism and aims to balance the disorders stemming from capitalism. While the tweets related to the calls for offline activism can be evaluated the indicators of activist motivation, the struggle and resistance initiatives of PEP has not translated into any mass political action. However, each effort and struggle call contributes to the democratic culture of Turkey and provides a circulation of different viewpoints in the public sphere.

\section{Conclusion}

Skeptical evaluations on social media revolution discuss whether an online activity can translate into offline situations and they acknowledge that social media is one important tool. We overestimate the power of social media when forming the arenas of the counter-hegemonic resistance, so we should think about what happens in reality. Are we able to change our life-world? I argue that social media might be limited, but it should not be ignored. Social media has a key role in diffusing the messages into the public and in creating networks of resistance to counter dominant power structures. The democratic natures of digital and social media allow the CSOs in sparking people's interest in the public issues. Even though digital practices are insufficient for influencing and determining major policies, they have essential functions related to organising, mobilising, informing, and promoting debate, as well as providing an alternative medium, and a counter-public sphere where collective identities can form. Public deliberations are encouraged on the websites and Twitter accounts of these kind of civil communities. Even though it is insufficient for influencing and determining major policies, the working class-related formations have an important function concerning organising, mobilising, informing, and promoting debate, as well as providing an alternative medium, and a counter-public sphere where collective identities can form.

The Internet is an alternative arena providing a new public sphere relevant to the protection of labour rights and the development of anti-capitalist policies. As online activist movements and their linked organisations and groups have no legal basis to influence political actors directly, they need to share their aims with the political public sphere. Therefore, they mobilise supporters by sharing their political agendas to create change in the political arena. It is not possible to say that digital platforms have the potential to subvert the system yet. However, the online presence of digital practices is necessary for political activism because of triggering offline activism. As Yesil (n.d.) emphasises, we should focus on their creative and insurgent capacities instead of evaluating their potential to dismantle the existing power structures.

\section{References}

Anduiza, E., Cantijoch, M. \& Gallego, A. (2009). Political Participation and the Internet: A Field Essay. Information, Communication \& Society, 12(6), 860-878. 
Aronowitz, S. (1992). The Politics of Identity: Class, Culture, Social Movements, New York: Routledge.

Bennett, W. L. (2003). New Media Power: The Internet and Global Activism, Contesting Media Power, In Nick Couldry and James Curran (Eds.), Lanham: Rowman and Littlefield.

Bohman, J. (2010). Expanding Dialogue: the Internet, the Public Sphere, and Prospects for Transnational Democracy (2004). In J. Gripsrud, H. Moe, A. Molander \& G. Murdock (Eds.). The Idea of the Public Sphere: A Reader (pp.247-269). Maryland: Lexington Books.

Bouvier, G. (2015) What Is a Discourse Approach to Twitter, Facebook, YouTube and Other Social Media: Connecting with Other Academic Fields? Journal of Multicultural Discourses, 10:2, 149-162, DOI: 10.1080/17447143.2015.1042381

Croteau, D. \& Hoynes, W. (2014). Media/Society: Industries, Images, and Audiences, Thousand Oaks, California: Sage.

Dahlgren, P. (2014). Social Media and Political Participation: Discourse and Deflection. In C. Fuchs and M. Sandoval (Eds.), Critique, Social Media and the Information Society (pp. 191-202). New York, NY: Routledge.

Dencik, L. and Wilkin, P. (2015). Worker Resistance and Media: Challenging Global Corporate Power in the 21st Century, New York: Peter Lang.

Feenberg, A. (2014). Great Refusal or Long March: How to Think about the Internet. In C. Fuchs \& M. Sandoval (Eds.), Critique, Social Media and the Information Society (pp. 109-124). New York: Routledge.

Fuentes, M. A. (2014). Digital Activism. In Encyclopedia Britannica, https://www.britannica.com/topic/digital-activism, Access Date: October 24, 2018.

Güner S. E. (June, 2016), “The Impact of Social Media on Political Change: Gezi Protests in Turkey”, Vol. V, Issue 6, pp.88-99, Centre for Policy and Research on Turkey (ResearchTurkey), London, Research Turkey. (http://researchturkey.org/?p=12181).

İnal, K., \& Akkaymak, G. (Edited by). 2012. Neoliberal Transformation of Education in Turkey. [Online] Available at: http://www.palgraveconnect.com/pc/doifinder/10.1057/9781137097811, (Accessed date: July 7 2016).

Jeffrey, S. J. (2008). Networking Futures: The Movements against Corporate Globalization, Durham: Duke University Press.

Kavada, A. (2005). Civil Society Organisations and the Internet: The Case of Amnesty International, Oxfam and the World Development Movement. In W. de Jong, M. Shaw and N. Stammers (Eds.), Global Activism, Global Media (pp. 208-222). London: Pluto Press.

Lynch, M. (2011). After Egypt: The Limits and Promise of Online Challenges to the Authoritarian Arab State. Perspectives on Politics, 9 (2), 301-310.

Lindgren, S. (2017). Digital Media \& Society, London: Sage.

Ludes, P., Nöth, W., \& Fahlenbrach, K. (2014). Introduction: Critical Visual Theory, tripleC 12 (1): 202-213, http://www.triple-c.at

McCaughey, M., \& Ayers, M. D. (Eds.) (2003). Cyberactivism: Online Activism in Theory and Practice, New York: Routledge.

Moore, S. (2011). New Trade Union Activism: Class Consciousness or Social Identity? Hampshire: Palgrave Macmillan.

Norris, P. (2007). Political Activism: New Challenges, New Opportunities. The Oxford Handbook of Comparative Politics, https://www.hks.harvard.edu/fs/pnorris/Acrobat/Boix\&stokes-chap26.pdf, Accessed Date: November 12, 2016.

Önder, N. (2016). The Economic Transformation of Turkey: Neoliberalism and State Intervention, London and New York: I.B.Tauris.

Pérez-Ahumada, P. (2015). The End of a Traditional Class Distinction in Neoliberal Society: 'White-collar' and 'Blue-collar' Work and its Impact on Chilean Workers' Class Consciousness, Critical Sociology, doi: 10.1177/0896920515585609

Plaza, E. P. (2018). "PEP Kimdir?” [Who is PEP?], https://plazaeylem.org/pep-hakkinda/, Access Date: 10 August 2018.

Tatarchevskiy, T. (2011). The 'Popular' Culture of Internet Activism. New Media \& Society, 13(2), 297-313, doi: $10.1177 / 1461444810372785$

Van, L. J., \& Van, A. P. (2010). Internet and Social Movement Action Repertoires: Opportunities and Limitations, Information, Communication \& Society, 13(8), 1146-1171.

Vegh, S. (2003). Classifying Forms of Online Activism: The Case of Cyberprotests against the World Bank, In Martha McCaughey \& Michael D. Ayers (eds.), Cyberactivism: Online Activism in Theory and Practice, New York: Routledge.

Wessel, B. (2014). Exploring Social Change: Process and Context. London: Palgrave.

Yesil, B. (n.d.). Social Media Use and Political Activism in Turkey: 140journos, the Post of Others, and Vote and Beyond. Civic Media Project. Retrieved Date: 19 August 2017. http://civicmediaproject.org/works/civic-media-project/uptakecitizenjournalism

Zadeh, I. H. (2016). US Presidential Election: Widespread Popular Discontent with Neoliberalism, Global Research, April 30, 2016, http://www.globalresearch.ca/us-presidential-election-widespread-popular-discontent-with-neoliberalism/5522509, Accessed Date: September 27, 2016. 